\title{
ERROR ANALYSIS OF STUDENTS' WRITING: A CASE STUDY OF EFL UNDERGRADUATE STUDENTS AT INDRAPRASTA PGRI UNIVERSITY
}

\author{
Herlina Lindaria Simanjuntak \\ Program of English Education, Faculty of Language and Art, University of Indraprasta PGRI \\ Jalan Nangka No. 58C Tanjung Barat, Jagakarsa, South Jakarta 12530 \\ herlinalindaria12@gmail.com
}

\begin{abstract}
The purpose of this research is to analyze grammatical error made by the third semester students of Indraprasta PGRI University in their writing. The researcher uses descriptive qualitative method in order to investigate errors in writing made by the three learners. The researcher used the descriptive analysis technique with the percentage of the data. The researcher limited the research of grammatical errors only for three categories namely omission, Misformation, and addition. The result shows that the total grammatical errors made by the three learners are 39 errors. The highest number of learner error was done in tenses, which is 19 errors or 48,7\%, preposition errors 12 errors or $30,8 \%$, and singular/plural noun 8 errors or $20,5 \%$. The most categories of errors made by the three learners were in omission 14 errors or 35,9\% and Misformation categories 14 errors or $35,9 \%$, meanwhile for the rest category, addition category 11 errors or $28,2 \%$. None participant made grammatical error on singular/plural noun of Misformation category. This research is very important because the teachers/lecturers could find out the appropriate strategy to teach and finally, it can improve the learners' skill of writing.
\end{abstract}

Key words: error analysis, grammatical, students' writing

\begin{abstract}
ABSTRAK
Tujuan penelitian ini untuk menganalisis kesalahan tata bahasa yang dibuat oleh mahasiswa semester tiga Universitas Indraprasta PGRI dalam penulisan karangan mereka. Penelitian ini menggunakan metode kualitatif deskriptif guna menginvestigasi kesalahan dalam menulis yang dibuat oleh tiga mahasiswa/i. Menyajikan data dalam bentuk presentase. Peneliti membatasi penelitian kesalahan tatabahasa ini hanya tiga kategori, yaitu penghilangan, kesalahan informasi, dan penambahan. Hasil penelitian ini menunjukkan bahwa jumlah kesalahan tatabahasa yang dibuat oleh ketiga mahasiswa/i tersebut adalah 39 kesalahan. Kesalahan terbanyak adalah kesalahan dalam tensis, yaitu 19 kesalahan atau 48,7\%, kata depan 12 kesalahan atau 30,8\%, dan kata benda tunggal/jamak 8 kesalahan atau 20,5\%. Sementara itu kesalahan terbanyak dalam hal kategoti ialah penghilangan 14 kesalahan atau 35,9\%, kesalahan informasi yaitu 14 kesalahan atau 35,9\%, sementara itu kesalahan kategori dalam hal penambahan sebanyak 11 kesalahan atau 28,2\%. Tak satupun dari mahasiswa membuat kesalahan tatabahasa kata benda tunggal/jamak untuk kategori kesalahan informasi. Penelitian ini sangat berfaedah karena para guru/dosen dapat menemukan strategi mengajar yang tepat. Pada akhirnya, dapat menambah keahlian mahasiswa
\end{abstract}


dalam penulisan mereka.

Kata kunci: analisis kesalahan, tata bahasa, penulisan mahasiswa

\section{INTRODUCTION}

It is not easy to study English as a Foreign Language (EFL) for Indonesian learners. In this case, of course, most of the Indonesian learners consider that Studying English is a challenging experience. The students might face many problems and difficulties because English language system is quite different with Indonesian such as grammar; for examples are tense, preposition, and singular/plural noun.

English has tense meanwhile Indonesian does not recognize it; even English has 16 tenses. English prepositions are very complex and so many, such as: to, on, it, in, before, under, into, onto, and so on, meanwhile Indonesian prepositions are very simple. English has the rule of singular/plural noun. Generally, most of nouns are added by "s" to form plural. Singular/plural noun related to subjectverb agreement; if the subject is singular the verb must be in singular too; for example, "She visits her grandmother every year". Meanwhile, vise versa if the subject is plural, the verb must be in plural too, for example, "They visit their grandmother every year".

Indonesian does not have subject-verb agreement. It might be the causes many Indonesian learners face the greatest problems when they translate from Indonesian into English and make errors in the process of learning English. Chomsky in Dulay, Burt and Krashen (1982) say that errors can be caused by two factors; (1) errors caused by factors such as fatigue and inattention (performance) and (2) errors caused by lack of knowledge of the rules of the language (competence). Performance errors are called 'mistakes' while errors refer to the systematic deviation because of the learners' still developing of the language. That's why to study English as a Foreign Language (EFL) for Indonesian learners, we must have four English skills.

The four English skills of the main purpose to study English as a Foreign Language such as; listening, speaking, reading, and writing. To be a master of English, of course the learners must have the four skills above well. Many learners feel that Writing is the most difficult and complex to be studied because the learners need to understand how to apply vocabulary and grammar properly. Writing is the activity or skill of marking coherent words on paper and composing text. Writing is a process constituting planning, drafting, revising, and editing. That is why, learner must have qualified grammar skills to produce a good writing. As Robinson and Modrey (1986) say that writing is a process. Writing is not an activity accomplished in one setting.

Writing skill is very useful to help learners communicate their ideas and their thoughts clearly. So that, the readers can truly understand the information they intend to convey. It can be said that writing is generally regarded as the most difficult skill to be learned not only because of the needs to master many skills of English; reading, speaking, and listening, but also because of the difference between the learners' native language rules and that of the language being learned. 
The researcher is very interested in researching of error analysis because error analysis is the most interesting issues; error analysis is important for both learners and teachers. Both learners and teachers get benefits; teachers get the information about the errors that learners do. Error analysis also can help the teacher how to improve their teaching; one of the important teaching processes is how to describe and explain errors made by learners. Another reason the researcher is very interested in researching of error analysis because it is said that making errors or mistakes in the process of learning as a second language is a natural process and should be considered as part of cognition. That is why error analysis research is a challenging experience.

Through analyzing the learners' errors, it is easier to the teacher to find out the appropriate strategy to teach. In this research, the researcher focuses on analyzing the most common errors made by the students of Indraprasta PGRI University. Its errors are grammatical errors, namely: tenses, prepositions, and singular/plural noun and also the strategical errors such as omissions, missionformation, and addition.

\section{METHOD}

In the error analysis of students' writing research, the researcher uses descriptive qualitative method. It aims to analyze learners' errors of their writing, to describe, and to explain the data. Based on Creswell (1998), McMillan and Schumacher (2006), as well as Cohen, Manion and Morrison (2007) affirm that qualitative research is an investigation process based on methodological inquiry that examines people's problems, actions, beliefs, thought, and perception.
The participants are three learners at the third semester of Indraprasta PGRI Universiry. Meanwhile there are forty students in that class. The researcher selected three of forty students because these three students' English skill are better than others. Therefore, the researcher assumes that they can give the important and appropriate information that the other people cannot do.

The researcher gives the written test to the three students at the third semester. Then, because of the researcher aims to conduct error analysis that is why the data are collected by using document analysis. This way is taken by the researcher to find out the data how many the students do errors in written test.

The data are classified, identified, described, and corrected which is the steps proposed by Corder as quoted in Ellis (1994). Meanwhile, Dulay et al., (1982) say that The data are described according to surface strategy taxonomy of errors. As said by Ellis (1994), classifying errors are omission, addition, Misformation and misordering. Omission is the absence of an item that must appear in a wellformed utterance. Addition is the presence of an item that must not appear in well-formed utterance. Misformation is the use of wrong form of the morpheme or structure. Misordering is the incorrect placement of a morpheme or group of morphemes in an utterance.

\section{RESULTS AND DISCUSSION}

In this research, the researcher focuses on analyzing three types of grammatical errors which are tenses, prepositions, and singular/plural noun made by learners in their writing. As said by James in Mungungu (2010), errors in tenses, prepositions, and singular/plural noun are categorized as 
grammatical error. The steps proposed by Corder in Ellis (1994) were used to examine the data. Afterward the data were classified into categories suggested by Dulay, Burt and Krashen (1982). To know the description of the grammatical errors in learners' writing, the researcher identified the grammatical errors such as tenses, prepositions, and singular/plural noun then they were reconstructed. And to know the description of the strategical errors, the researcher identified omissions, misformations, and addition.

Table 1

Most Common Errors of Participant 1

\begin{tabular}{|c|c|c|}
\hline \multirow[t]{9}{*}{ Tenses } & $\begin{array}{l}\text { Angel the most beautiful student. } \\
\text { (Omission) }\end{array}$ & Angel is the most beautiful student. \\
\hline & $\begin{array}{l}\text { She bored school so she decided to } \\
\text { drop out. } \\
\text { (Omission) }\end{array}$ & $\begin{array}{l}\text { She was bored school so she decided to } \\
\text { drop out. }\end{array}$ \\
\hline & $\begin{array}{l}\text { My friend walk three kilometers every } \\
\text { day. } \\
\text { (Misformation) }\end{array}$ & $\begin{array}{l}\text { My friend walks three kilometers every } \\
\text { day. }\end{array}$ \\
\hline & $\begin{array}{l}\text { Edwin a Pilot. } \\
\text { (Omission) }\end{array}$ & Edwin is a pilot. \\
\hline & $\begin{array}{l}\text { I choose to study at Unindra University. } \\
\text { (Misformation) }\end{array}$ & I chose to study at Unindra University. \\
\hline & Are you married? & \\
\hline & No. I did not married. & Are you married? \\
\hline & (Misformation) & No. I am not married. \\
\hline & $\begin{array}{l}\text { I was discussed my skripsi. } \\
\text { (Adition) }\end{array}$ & I discussed my skripsi. \\
\hline \multirow[t]{2}{*}{ Preposition } & $\begin{array}{l}\text { My house is near from my campus. } \\
\text { (Adition) }\end{array}$ & $\begin{array}{l}\text { My house is near my campus, just a few } \\
\text { hundred meters way. }\end{array}$ \\
\hline & $\begin{array}{l}\text { Ria is very familiar for me. } \\
\text { (Misformation) }\end{array}$ & Ria is very familiar to me. \\
\hline
\end{tabular}

Table 2

Most Common Errors of Participant 2

\begin{tabular}{ll}
\hline Tenses & I was the first winner in the class \\
(Misformation) & I am so happy today \\
I so happy today & \\
(Omission) & \\
I am so sorry sir, I did not know where & Sorry Sir, I don't know where \\
Olivia's house is & Olivia's house is
\end{tabular}

(Misformation) 
Brenda had has ever visited Paris

(Adition)

Indonesia have more then 17.000 Indonesia has more than seventeen islands

(Misformation)

\begin{tabular}{|c|c|c|}
\hline \multirow[t]{4}{*}{ Prepositions } & $\begin{array}{l}\text { Brenda will go Germany next year } \\
\text { (Omission) }\end{array}$ & Brenda will go to Germany next year \\
\hline & $\begin{array}{l}\text { Edwin is very interested to flight } \\
\text { world }\end{array}$ & $\begin{array}{l}\text { Edwin is very interested in world } \\
\text { flight }\end{array}$ \\
\hline & (Misformation) & \\
\hline & $\begin{array}{l}\text { Lintang looks at to me shyly } \\
\text { (Adition) }\end{array}$ & Lintang looks at me shyly \\
\hline \multirow[t]{4}{*}{$\begin{array}{l}\text { Sigular/plural } \\
\text { noun }\end{array}$} & $\begin{array}{l}\text { They are in home right now } \\
\text { (Misformation) }\end{array}$ & They are at home right now \\
\hline & $\begin{array}{l}\text { She study Unindra university } \\
\text { (Omission) }\end{array}$ & She study at Unindra university \\
\hline & $\begin{array}{l}\text { There are twenty student in my class } \\
\text { (Omission) }\end{array}$ & There are twenty students in my class \\
\hline & $\begin{array}{l}\text { My father's office is on the twenty } \\
\text { second floors (Adition) }\end{array}$ & $\begin{array}{l}\text { My father's office is on the twenty } \\
\text { second floor }\end{array}$ \\
\hline
\end{tabular}

Table 3

Most Common Errors of Participant 3

Tenses I visits my grandma every month. I visit my grandma every month.

(Misformation)

This movie is really bored.

This movie is really boring.

(Misformation)

Hmmm. You late again.

Hmm. You are late again.

(Omission)

They are go to school together every They go to school together every day. day.

\section{(Adition)}

I ever seen you sister.

I Have ever seen you sister.

(Omission)

He send me two packets yesterday. He sent me two packets yesterday.

(Misformation) 
I clean the table a few minutes ago, I cleaned the table a few minutes ago, mom. mom.

(Misformation)

\begin{tabular}{|c|c|c|}
\hline \multirow[t]{11}{*}{ Preposition } & $\begin{array}{l}\text { This table is made by teak wood. } \\
\text { (Misformation) }\end{array}$ & This table is made of teak wood. \\
\hline & $\begin{array}{l}\text { The plane took smoothly. } \\
\text { (Omission) }\end{array}$ & The plane took off smoothly. \\
\hline & $\begin{array}{l}\text { I am not interested in to your offer. } \\
\text { (Adition) }\end{array}$ & I am not interested in your offer. \\
\hline & $\begin{array}{l}\text { I sincerely take care you, my beloved } \\
\text { brother. (Omission) }\end{array}$ & $\begin{array}{l}\text { I sincerely take care of you, my } \\
\text { beloved brother. }\end{array}$ \\
\hline & $\begin{array}{l}\text { He glanced at to me with a smile. } \\
\text { (Adition) }\end{array}$ & He glanced $\boldsymbol{a t}$ me with a smile. \\
\hline & $\begin{array}{l}\text { I have been here for seven } d a y \text {. } \\
\text { (Omission) }\end{array}$ & I have been here for seven days. \\
\hline & $\begin{array}{l}\text { My friends, Anastasia will go to } \\
\text { America next month. } \\
\text { (Adition) }\end{array}$ & $\begin{array}{l}\text { My friend, Anastasia will go to } \\
\text { America next month. }\end{array}$ \\
\hline & $\begin{array}{l}\text { Robert ordered } \boldsymbol{a} \text { bottles of water. } \\
\text { (Adition) }\end{array}$ & Robert ordered $\boldsymbol{a}$ bottle of water. \\
\hline & $\begin{array}{l}\text { One of my car is red. } \\
\text { (Omission) }\end{array}$ & One of my cars is red. \\
\hline & $\begin{array}{l}\text { My mother fries many fried bananas } \\
\text { every days. (Adition) }\end{array}$ & $\begin{array}{l}\text { My mother fries many fried bananas } \\
\text { every day. }\end{array}$ \\
\hline & I need a lot of book. (Omission) & I need a lot of books. \\
\hline
\end{tabular}

Table 4

Categories of Errors

\begin{tabular}{|c|c|c|c|c|c|c|c|c|c|c|c|c|c|}
\hline \multirow{2}{*}{ Participant } & \multicolumn{4}{|c|}{ Tenses } & \multicolumn{4}{|c|}{ Preposition } & \multicolumn{4}{|c|}{ S/Pn } & \multirow{2}{*}{$\begin{array}{c}\text { Grand } \\
\text { Total }\end{array}$} \\
\hline & $\mathbf{O}$ & $\mathbf{M}$ & $\mathbf{A}$ & Total & $\mathbf{O}$ & $\mathbf{M}$ & $\mathbf{A}$ & Total & $\mathbf{O}$ & $\mathbf{M}$ & $\mathbf{A}$ & Total & \\
\hline 1 & 3 & 3 & 1 & 7 & - & 1 & 1 & 2 & - & - & - & $\mathbf{0}$ & 9 \\
\hline 2 & 1 & 3 & 1 & 5 & 2 & 2 & 1 & 5 & 1 & - & 1 & 2 & 12 \\
\hline 3 & 2 & 4 & 1 & 7 & 2 & 1 & 2 & 5 & 3 & - & 3 & 6 & 18 \\
\hline $\begin{array}{c}\text { Grand } \\
\text { Total }\end{array}$ & 6 & 10 & 3 & 19 & 4 & 4 & 4 & 12 & 4 & 0 & 4 & 8 & 39 \\
\hline
\end{tabular}

According to the table 4, the researcher found that the total number or the errors made in grammatical is 39 errors. The highest number of learner 105 error was done in tenses, which was 19 errors or $48,7 \%$. It could be said that tense was the most difficult one for learners. The most common errors 05 Scope: Journal of English Language Teaching, Vol: 03, Issue 02, March 2019, 100-108 
made by the learners in tenses were they applied the wrong verbs in the sentence, namely misformations, which were ten errors from total 19 errors of tenses. The first participant made 7 errors on tense that were caused by 3 omissions, three misformations, and one addition.

Meanwhile, the second participant made five errors on tense that were caused by one omission, three misformations, and one addition. Therefore, the last partipant made seven errors on tense that were caused by two omissions, four misformations, and one addition. All participants are still lack of the knowledge present tense. For example If the subject is the third singular person (he, she), it must be followed by the verb + s/es . For example is "My friend walk three kilometers every day", Friend is the third singular person so it must be "My friend walks three kilometers every day". Then, they cannot differ how to use present tense or past tense. They have not understood yet that how to apply auxiliary be. The mastery of learner tenses is still weak. The difficulties that the three participants face on tense it might be caused of Indonesian language role does not have tense.

According to Borjas and Burridge (2010), a preposition is a word that is used to indicate the relationship between a noun or pronoun and other words in a sentence. The learners made twelve errors on prepositions, it means that $30,5 \%$ from the total number of grammatical errors which was 39 errors. However, the learners face prepositional learning difficulties; it can be seen from the tables above. The first participant made two errors, which were caused by one Misformation and one addition, and vise versa, no error which was caused by omission.
The second participant made five preposition errors which were two omission, two misformations, and one addition. Further, the last participant and the second one had the same number of errors in preposition which were caused by two omissions, one Misformation, and two additions. All participants tended to apply the wrong prepositions in a particular sentence. Even, they also omitted some prepositions in their sentence. Of course it changed the meaning of their sentences.

It is clear from the tables above that two of three participants had errors in using singular and plural noun in their sentences. Participant two made two errors which were one omission and one addition. The third participant had six errors in singular/plural noun which were three omissions, and three additions. Meanwhile the first participant had no error in this type. It can be said that the first participant recognized the preposition. The second and the third participant made on preposition errors may occur because there is no plural marker for a noun in Indonesia role. To change the form singular noun into plural uses repeatation; Indonesia repeats the same noun for plural noun, such as 'Siswasiswa' for 'students', meanwhile it uses suffix "S" for plural noun in English," There are twenty students in my class".

According to the table 3, the researcher found that the total number of the errors made in strategical errors were on omissions 14 or $35,9 \%$. The example of omission error is Angel the most beautiful student it must be into Angel is the most beautiful student. It is stated that the absence of an item that must appear in well-formed utterance. In this case the omission error was "is". 
Misformation 14 or $35,9 \%$. The example of Misformation error is My friend walk three kilometers every day it must be My friend walks three kilometers every day. In this case, Misformation, the leaner used the wrong form of the morpheme or structure. The Misformation error was "walks".

And addition 11 or $28,2 \%$. The example of addition error is Lintang glanced at to me shyly. It must be into Lintang glanced at me shyly. Addition is the presence of an item that must not appear in well-formed utterance. In this case the learner applied the presence of an item that must not appear in wellformed utterance, namely preposition "to". It occurred maybe the learners did not understand the eight parts of speech.

\section{CONCLUSION}

According to table no 4, the total grammatical errors made by the third semester students of Indraprasta PGRI university in writing are 39. Based on the data, it was found that the grammatical errors in writing were in tenses for the highest error by 19 errors or $48,7 \%$, the second is errors in preposition by 12 errors or $30,8 \%$, and the third is errors in singular/plural noun by 8 errors or $20,5 \%$. It can be seen that the third participant making the most errors, there were 18 erros or $47 \%$ of the total errors. She made seven errors in tenses, five errors in prepositions, and six errors in singular/plural noun. The second participant was second place making the errors. He made twelve errors; five errors in tenses, five errors in preposition, and two errors in singular/plural noun. Meanwhile the third participant was the least participant making the errors. She made seven errors in tenses, two errors in preposition, and none error in singular/plural noun.

Based on the categories of errors, the most errors made by the participants were in omissions and misformation categories. Meanwhile for the rest category, addition category, Participant 1 made two errors in addition category, participants two made three errors in addition and, the third participant made six errors in addition category. None participant made grammatical error on singular/plural noun of misformation category. And based on categorical errors, the two most errors were omission and misformation, meanwhile addition was the least one.

It is not easy to avoid learner errors in studying English as the Foreign Language for Indonesian learners. That is why the learners should study more about grammar, especially the eight parts of speech. To the teacher, they should improve their teaching system and to find out the appropriate strategy to teach. This research is very important because the teachers/lecturers could find out the appropriate strategy to teach and finally, it can improve the learners' skill of writing.

The researcher really expects that this research could give contribution to English teaching system in Indonesia, especially in writing. The researcher realizes that this research is not perfect. It was caused that the limitations of this research were the small number of participants and data collection. It is expected that, for further research the researcher will examine more participants and data collection.

\section{REFERENCES}

Borjas, K. \& Burridge, K. (2010). Introducing English Grammar 
(2 $2^{\text {nd }} E d$ ). London: Hodder Education.

Cohen, L., Manion, L., \& Morrison, K. (2007). Research Methods in Education ( $6^{\text {th }}$ Ed). London: Routledge.

Creswell, J. W. (1998). Qualitative inquiry and Research design: Choosing among five tradition. California: SAGE Publication, Inc.

Dulay, H., Burt, M., \& Krashen, S. (1982). Language Two. New York: Oxford University Press.
Ellis, R. (1994). The Study of second Language Acquisition. Oxford: Oxford University Press.

Mcmillan, J. H., \& Schumacher, S. (2006). Research in Education. A Conceptual Introduction ( $5^{\text {th }} \mathrm{Ed}$ ). Boston: Addison Wesley Longman, Inc.

Mungungu, S. S. (2010). Error Analysis: Investigating the Writing of ESL Namibian Learners. (Master), University at South Africa, Pretonia.

Robinson, T. H., \& Modrey, L. (1986). Active Writing. New York: Macmilan Publishing Company. 